Original Article

\title{
PHYTOCHEMICAL EVALUATION OF PUNICA GRANATUM L. LEAF EXTRACT
}

\author{
P. SREEDEVI ${ }^{1}$, K. VIJAYALAKSHMI ${ }^{2}$, R. VENKATESWARI ${ }^{3}$
}

1,2Department of Biochemistry, Bharathi Women's College, ${ }^{3}$ Department of Medical Biochemistry, University of Madras, Taramani Campus Email: viji42research@yahoo.co.in

Received: 27 Dec 2016, Revised and Accepted: 27 Mar 2017

\section{ABSTRACT}

Objective: This study was conducted to assess the phytochemical constituents in Punica granatum L. Leaf extracts (PGLE) using standard methods.

Methods: The leaf powder was extracted using solvents namely aqueous, hydroalcohol, ethanol, ethyl acetate and n-hexane. Qualitative and Quantitative phytochemical screenings of PGLE were assessed by standard methods.

Results: All the leaf extracts were positive for a wide range of bio-active compounds except $\mathrm{n}$-hexane. The result has showed that the maximum amount of total phenols (394.16 mg/g DW of extract), total tannins (210.5 mg/g DW of extract), flavanoids $(147.4 \mathrm{mg} / \mathrm{g}$ DW of extract) and total triterpenoids $(112 \mathrm{mg} / \mathrm{g}$ DW of extract) were noted in ethanolic extract of P. granatum leaf (EPGL). The biological assay revealed that relevant amount of carbohydrate, protein, lipid and alkaloid in EPGL

Conclusion: The findings of this study concluded that the EPGL had potential bioactive substances that may be used as pharmaceutical ingredients for formulation of new or prospective potent drug to cure wide range of metabolic diseases.

Keywords: Punica granatum, Phytochemical constituents, Total phenols, Tannins flavonoids and triterpenoids

(C) 2017 The Authors. Published by Innovare Academic Sciences Pvt Ltd. This is an open access article under the CC BY license (http://creativecommons.org/licenses/by/4.0/) DOI: http://dx.doi.org/10.22159/ijcpr.2017v9i4.1159

\section{INTRODUCTION}

Medicinal plants play a major role in meeting the medicinal and health needs of about $70 \%$ of populations in developed and developing countries, which serve as an important resource for the treatment of various maladies and illnesses [1].

Plants synthesize a wide range of chemical compounds which are classified based on their chemical class, biosynthetic origin and functional groups into primary and secondary metabolites. Primary metabolites directly involved in growth and development while secondary metabolites are not involved directly and they have been worked as biocatalysts. Primary metabolites are widely distributed in nature, occurring in one form or another in virtually all organisms. They are chlorophyll, amino acids, nucleotides, carbohydrates and so on, which have a key role in metabolic processes such as photosynthesis, respiration and nutrient assimilation. They are used as industrial raw materials and food additives. Secondary metabolites are synthesized during secondary metabolism of plants. They are the basic source for the establishment of several pharmaceutical industries since they have enormous medicinal properties [2]. The most important secondary metabolites are alkaloids, tannins, flavonoids, phlobatannins, saponins and cardiac glycosides. All secondary metabolites have specific function such as saponins have antifungal activity [3], some alkaloid may be useful against HIV infection [4], flavonoids have strong anticancer activity [5] and tannin have antimicrobial activity.

In the search for phytochemicals that may be of benefit to the pharmaceutical industry, researchers sometimes follow leads provided by local healers in a region [6]. Following such leads, plant parts are usually screened for phytochemicals that may be present. The presence of a phytochemical of interest may lead to its further isolation, purification and characterization. Then it can be used as the basis for a new pharmaceutical product. Successful determination of biologically active compounds from plant material is largely dependent on the type of solvent used in the extraction procedure [7]. This therefore underscores the need to try as much solvents as possible in screening plant parts for phytochemicals.

Punica granatum belongs to the family Punicaceae, commonly known as pomegranate, is a shrub or small tree with several upright, thorny stems, the leaves are elliptic, roughly 2 inches, the flowers are white or red, double-flowered races, native of Asia and Mediterranean Europe [8]. It is also found in India and more arid regions of Southeast Asia, [9] the East Indies, and tropical Africa. For centuries, the barks, leaves, flowers, fruits and seeds of this plant have been used to ameliorate diseases [10]. The potential therapeutic properties of pomegranate are wide-ranging and include treatment and prevention of cancers, cardiovascular disease, diabetes, dental conditions, erectile dysfunction and prevention from ultra violet (UV) radiation. The pericarp of $P$. granatum is used to treat infections found in human sexual organs as well as mastitis, acne, folliculitis, piles, allergic dermatitis, tympanitis, scalds, diarrhoea and dysentery [11].

Considering all these facts, the present study was designed to investigate the presence of various phytochemicals in the different extracts of Punica granatum leaf, a plant which evokes various therapeutic effects.

\section{MATERIALS AND METHODS}

\section{Preparation of leaf extracts}

Leaves of pomegranate plant (Punica granatum L.) were obtained from around the Sathyavedu village, Andhra Pradesh, India. The Punica granatum leaf was authenticated by Dr. P. Jayaraman, Director of National Institute of Herbal science, Plant anatomy research centre, Chennai.

The leaves of the plant were carefully removed and thoroughly washed with distilled water to remove dust particles. They were dried in shade and finely powdered using an electric blender. Fifty grams of powdered material was subjected to Soxhlet extraction with $500 \mathrm{ml}$ of $\mathrm{n}$-Hexane, ethyl acetate, ethanol, hydroalcohol and water separately for $8 \mathrm{~h}$. The extracts were evaporated to dryness under controlled temperature $\left(35-40{ }^{\circ} \mathrm{C}\right)$. The extracts were stored in air tight containers under refrigeration. These dried extracts were dissolved in respective solvents and used for further analysis.

Qualitative Phytochemical screening: Phytochemical screening of Punica granatum Leaf extracts were assessed by standard methods (12-15).

Test for alkaloids

A fraction of extract was treated with 3-5drops of Wagner's reagent [1.27g of iodine and $2 \mathrm{~g}$ of potassium iodide in $100 \mathrm{ml}$ of water] and 
formation of reddish brown precipitate (or colouration) indicates the presence of alkaloids.

\section{Test for anthraquinone}

To $1 \mathrm{ml}$ of plant extract, few drops of $1 \% \mathrm{HCl}$ were added. Appearance of red colour precipitate indicates the presence of anthraquinone.

\section{Test for carbohydrates}

$1 \mathrm{ml}$ of plant extract was mixed with alpha napthol solution and then to the sides of the test tube conc. $\mathrm{H}_{2} \mathrm{SO}_{4}$ is added. Appearance of violet ring indicates the presence of carbohydrates.

\section{Test for reducing sugar}

$1 \mathrm{ml}$ of plant extract was mixed with few drops of Benedict's reagent and kept in boiling water bath, observed for the formation of reddish brown precipitate. A positive result shows the presence of reducing sugar.

\section{Test for flavanoids}

$2 \mathrm{ml}$ of extracts was treated with few drops of $20 \%$ sodium hydroxide solution. Formation of intense yellow colour, which becomes colourless on addition of dilute hydrochloric acid, indicates the presence of flavonoids.

\section{Test for phenols}

A portion of the extract was treated with aqueous $5 \%$ ferric chloride and formation of deep blue or black colour indicates the presence of phenols.

\section{Test for proteins}

To the extract, $1 \mathrm{ml}$ of distilled water was added which was then heated with Biuret reagent and observed for the formation of violet/pink colour.

\section{Test for free amino acids}

The extract was heated with $0.2 \%$ solution of Ninhydrin which result in the formation of purple colour, suggesting the presence of free amino acid.

\section{Test for coumarins}

To $2 \mathrm{ml}$ of the test solution, a few drops of $10 \% \mathrm{NaOH}$ were added. Appearance of yellow colour indicates the presence of coumarins.

\section{Test for saponins}

$2 \mathrm{ml}$ of extract was added to $6 \mathrm{ml}$ of distilled water in a test tube. The mixture was shaken vigorously and observed for the formation of persistent foam that confirms the presence of Saponins.

\section{Test for steroids}

$1 \mathrm{ml}$ of extract was treated with few drops of chloroform, acetic anhydride and conc. H2SO4 and formation of dark pink or red colour indicated the presence of steroids.

\section{Test for tannins}

$2 \mathrm{ml}$ of extract was treated with $10 \%$ alcoholic ferric chloride solution and formation of blue or greenish colour solution indicated the presence of tannins.

\section{Test for terpenoids}

$1 \mathrm{ml}$ of chloroform was added to $2 \mathrm{ml}$ of each extract followed by a few drops of concentrated sulphuric acid. A reddish brown precipitate produced immediately indicated the presence of terpenoids.

\section{Quantitative phytochemical analysis}

\section{Estimation of total phenolic content (TP)}

The total phenolic compound in the extract was determined by the Folin-Ciocalteau method. An aliquot of sample $(0.2 \mathrm{ml})$ was mixed with $0.5 \mathrm{ml}$ of Folin-Ciocalteau reagent (1: 2 dilution) and $4 \mathrm{ml}$ of sodium carbonate $(1 \mathrm{M})$ and allowed to stand for $30 \mathrm{~min}$ at room temperature. The absorbance was measured at $750 \mathrm{~nm}$ using a spectrophotometer (Beckman, DU 7400 USA). TP content in the extract was calculated and expressed as mg of Chlorogenic acid equivalent per g of dry weight of extract (mg CGE/g DW) [16].

\section{Estimation of tannins}

The tannin present in extracts of $P$. granatum was determined by the method of Peri and Pompei, 1971 [17]. $0.5 \mathrm{ml}$ of extract was made upto $2 \mathrm{ml}$ with distilled water and $2 \mathrm{ml}$ of water serves as blank. To this $0.5 \mathrm{ml}$ of Folin ciocalteau phenol reagent (1:2 dilution) followed by the addition of $5 \mathrm{ml}$ of $35 \%$ sodium carbonate and kept at room temperature for $5 \mathrm{~min}$. Blue colour formed was read at $640 \mathrm{~nm}$. A standard graph (Chlorogenic acid) was plotted, from which the tannin content of the extracts was determined. The total tannin content was expressed in $\mathrm{mg} \mathrm{CGE/g} \mathrm{DW} \mathrm{of} \mathrm{extract.}$

\section{Estimation of flavonoids}

The TFC (total flavonoid content) of P. granatum leaf extract was determined using the aluminium chloride assay by colorimetry. An aliquot $(0.5 \mathrm{ml})$ of extract was taken in different test tubes then $2 \mathrm{ml}$ of distilled water was added followed by the addition of $0.15 \mathrm{ml}$ of sodium nitrite $\left(5 \% \mathrm{NaNO}_{2}, \mathrm{~W} / \mathrm{V}\right)$ and allowed to stand for $6 \mathrm{~min}$, $0.15 \mathrm{ml}$ of aluminium trichloride $\left(10 \% \mathrm{AlCl}_{3}\right)$ was added and incubated for $6 \mathrm{~min}$, followed by the addition of $2 \mathrm{ml}$ of sodium hydroxide $(\mathrm{NaOH}, 4 \% \mathrm{~W} / \mathrm{V})$. The solution was well vortexed and absorbance was measured against reagent blank at $510 \mathrm{~nm}$. The total flavonoid content $(\mathrm{mg} / \mathrm{g})$ was determined from the calibration curve of quercetin and expressed as mg quercetin equivalents (mg QE/g DW) $[18,19]$.

\section{Estimation of total triterpenoids}

Briefly $200 \mu$ sample solution in a $10 \mathrm{ml}$ volumetric flask was heated to evaporation in a water bath, $1 \mathrm{ml}$ of $5 \%(\mathrm{~W} / \mathrm{V})$ vanillin-acetic acid solution and $1.8 \mathrm{ml}$ sulphuric acid were added, mixed and incubated at $70{ }^{\circ} \mathrm{C}$ for $30 \mathrm{~min}$. Then the solution was cooled and diluted to 10 $\mathrm{ml}$ with acetic acid. The absorbance was measured at $573 \mathrm{~nm}$ against blank using spectrophotometer. The blank consisted of all reagents and solvents without sample solution. The triterpenoids was determined using the standard ursolic acid and expressed as milligram of ursolic acid equivalent/gram dry weight of extract (mg UE/g DW) [20].

\section{Estimation of carbohydrates}

$0.2 \mathrm{ml}$ of extract was made up to $1.0 \mathrm{ml}$ with distilled water. $4.0 \mathrm{ml}$ of anthrone reagent $(0.2 \%$ anthrone in ice cold conc. Sulphuric acid) was added and kept in boiling water bath for $8 \mathrm{~min}$, cooled rapidly and read at $630 \mathrm{~nm}$. The blank consisted of all reagents without sample solution. D-glucose was used as standard. The total sugar content was expressed in terms of percentage of dry weight [21].

\section{Estimation of proteins}

$0.2 \mathrm{ml}$ of extract was made to $1.0 \mathrm{ml}$ with distilled water. $5.0 \mathrm{ml}$ of alkaline copper reagent was added to all the tubes and allowed to stand for $10 \mathrm{~min}$. Then $0.5 \mathrm{ml}$ of Folin's Ciocalteau reagent was added and incubated in dark for $30 \mathrm{~min}$. The intensity of the colour developed was read at $660 \mathrm{~nm}$. The blank consisted of all reagents without sample solution. The protein content was determined using the standard Bovine serum albumin and expressed in terms of percentage of dry weight [22].

\section{Estimation of total lipids}

$10 \mathrm{gm}$. sample was used to extract lipids with $150 \mathrm{ml}$ of petroleum ether for $16 \mathrm{hr}$., at a solvent condensation rate of 2-3 drops/sec. The obtained extract was concentrated and evaporated at room temperature to dryness. The weight of extract gives the total lipid content which was expressed in terms of percentage of dry weight [23].

\section{Alkaloid determination by harborne (1973) method}

$5 \mathrm{~g}$ of the sample was weighed and added to $250 \mathrm{ml}$ beaker and 200 $\mathrm{ml}$ of $10 \%$ acetic acid in ethanol was added and covered and allowed to stand for $4 \mathrm{~h}$. This was filtered and the extract was concentrated 
on a water bath to one-quarter of the original volume. Concentrated ammonium hydroxide was added drop wise to the extract until the precipitation was complete. The whole solution was allowed to settle and the precipitate was collected and washed with dilute ammonium hydroxide and then filtered. The residue is the alkaloid, which was dried, weighed and expressed in terms of percentage of dry weight [24].

\section{RESULTS AND DISCUSSION}

\section{Preliminary phytochemical analysis}

The preliminary phytochemical tests are helpful in finding chemical constituents in the plant material that may lead to their quantitative estimation and also in locating the source of pharmacologically active chemical compound.

Table 1: Qualitative phytochemical analysis

\begin{tabular}{|c|c|c|c|c|c|c|}
\hline $\begin{array}{l}\text { S. } \\
\text { No. }\end{array}$ & $\begin{array}{l}\text { Phytochemical } \\
\text { constituent }\end{array}$ & $\begin{array}{l}\text { Aqueous } \\
\text { extract }\end{array}$ & $\begin{array}{l}\text { Hydroalcohol } \\
\text { extract }\end{array}$ & $\begin{array}{l}\text { Ethanol } \\
\text { extract }\end{array}$ & $\begin{array}{l}\text { Ethyl acetate } \\
\text { extract }\end{array}$ & $\begin{array}{l}\text { n-hexane } \\
\text { extract }\end{array}$ \\
\hline 1 & Alkaloid & + & + & + & + & - \\
\hline 2 & Carbohydrate & + & + & + & + & + \\
\hline 3 & Reducing sugar & + & + & + & + & + \\
\hline 4 & Flavanoid & + & + & + & + & _- \\
\hline 5 & Phenol & + & + & + & + & + \\
\hline 6 & Protein & + & + & + & + & _- \\
\hline 7 & Amino acid(free) & - & - & - & - & - \\
\hline 8 & Coumarin & + & + & + & + & - \\
\hline 9 & Saponin & + & _ & _- & _ & - \\
\hline 10 & Tannin & + & + & + & + & + \\
\hline 11 & Steroids & _ & + & + & + & + \\
\hline 12 & Terpenoids & + & + & + & + & _- \\
\hline 13 & Anthraquinone & _ & _ & _ & _- & _ \\
\hline
\end{tabular}

Table 2: Quantification of secondary metabolites of punica granatum leaf extract

\begin{tabular}{llllll}
\hline $\begin{array}{l}\text { S. } \\
\text { No }\end{array}$ & Extract & $\begin{array}{l}\text { Total phenols (mg of } \\
\text { CGE/g of dry extract) }\end{array}$ & $\begin{array}{l}\text { Tannins (mg of CGE/g } \\
\text { of dry extract) }\end{array}$ & $\begin{array}{l}\text { Flavanoids (mg of } \\
\text { QE/g of dry extract) }\end{array}$ & $\begin{array}{l}\text { Total triterpenoids(mg of UE/g of } \\
\text { dry extract) }\end{array}$ \\
\hline 1 & Water Extract & $274.1 \pm 0.65$ & $90.9 \pm 0.26$ & $77.26 \pm 0.8$ & $44.9 \pm 1.55$ \\
2 & Hydro alcohol & $117.6 \pm 0.76$ & $73.6 \pm 0.52$ & $66.3 \pm 1.25$ & \\
& Extract & & & & \\
3 & Ethanol Extract & $394.16 \pm 0.76$ & $21.73 \pm 1.67$ & $147.4 \pm 1.0$ & $3.5 \pm 0.5$ \\
4 & Ethyl acetate & $240.8 \pm 0.28$ & $141.6 \pm 0.59$ & $33.3 \pm 1.5$ & \\
& Extract & & & & $37.3 \pm 0.92$ \\
\hline
\end{tabular}

Values are expressed as mean $\pm \operatorname{SD}(n=4)$.

Table 3: The alkaloid content and calorific value of ethanolic extract of punica granatum Leaf in percentage

\begin{tabular}{ll}
\hline Alkaloid & $\mathbf{3 . 5 + 1 . 5}$ \\
\hline Carbohydrates & $19.6 \pm 2.3$ \\
Proteins & $11.86 \pm 0.9$ \\
Lipids & $0.96 \pm 1.7$ \\
\hline
\end{tabular}

Values are expressed in percentage $(n=4)$

The qualitative analysis of bioactive compounds for the five extracts have been analysed in this study and there is wide range of phytochemical compounds present in the five extracts as shown in table 1 . The hexane being highly nonpolar in nature was able to extract very less compound characterized like carbohydrates, phenols, steroids and tannins. Ethanolic extract, ethyl acetate and hydro alcoholic extract was found to have a wide range of bioactive compounds like alkaloids, carbohydrates, coumarins, flavonoids, proteins, phenols, reducing sugars, steroids and tannins.

The aqueous extract found to have bioactive constituent said above in addition to saponins except steroids. The presence of bioactive constituents indicates that the P. granatum Leaf extract can be used in a multitude of ways for the beneficiary of population.

The results for quantitative analysis of the P. granatum leaf extract are illustrated in table 2. Ethanolic extract was found to possess the maximum amount of Phenols (394.16 mg of CGE/g of DW), Tannins (210.5 mg CGE/g of DW), Flavanoids (147.4 mg of QE/g of DW) and total triterpenoids (112 mg of UE/g of DW). Since the yield of bioactive metabolites in a plant extract also varies considerably with the $(25,26)$ method/solvent of extraction it is plausible that the ethanolic extracts were generally more potent than the aqueous extracts probably because the active principles in the plant dissolved more readily in and were better extracted by a less polar solvent (ethanol) than water. This is in agreement with many literatures reporting the differences in the activities of extracts obtained from the same morphological part of a plant using different solvents. The methanolic extract of the fruits of Tetrapleura tetraptera is more potent than the aqueous [27] extract. Next to ethanolic extract, the water extract have higher content of total phenols $(274.1 \mathrm{mg}$ of CGE/g of DW) and flavonoids (77.26 mg of QE/g of DW) except tannins ( $90.9 \mathrm{mg}$ of CGE/g of DW) and total triterpenoids $(44.9 \mathrm{mg}$ of UE/g of DW). The quantity of total phenols (117.6 mg of CGE/g of DW) and tannins (73.6 mg of CGE/g of DW) were found to be lowest in hydroalcohol extract except flavonoids (66.3 $\mathrm{mg}$ of $\mathrm{QE} / \mathrm{g}$ of DW) and total triterpenoids (71.73 mg of UE/g of DW). Considerable amount of total phenols (240. $8 \mathrm{mg}$ of CGE/g of DW) and tannins (141.6 mg of CGE/g of DW) existed in ethyl acetate but found to have lowest amount of flavonoids (33.3 $\mathrm{mg}$ of $\mathrm{QE} / \mathrm{g}$ of $\mathrm{DW}$ ) and total triterpenoids (37.3 $\mathrm{mg}$ of UE/g of DW). These results were in agreement with Pande and Akoh [28]. They found that the total polyphenols was $365 \mathrm{mg} \mathrm{GAE} / \mathrm{g}$ of FW in P. granatum leaves. Similar results were given by Hemayet Hossain et al., (29), total phenolic content given as $378.37 \pm 0.92 \mathrm{mg}$ of gallic acid/g of dry extract. 
The medicinal value of plants lies in some chemical substances that have a definite physiological action on the human body. Different phytochemicals have been found to possess a wide range of activities, which may help in protection against chronic diseases [30].

Flavonoids have been used against the cancer causing tumours and it inhibits the promotion of growth and progression of tumours [31]. Phenols when mixed with the flavonoids compounds in plants are reported to show multiple activities like antioxidant, anticarcinogenic, anti-inflammatory etc. [32]. Plants with tannins are used for healing of wounds, varicose ulcers, haemorrhoids, frost-bite and burns [33, 34]. Terpenoids are reported to have antiinflammatory, anti-viral, anti-malarial, inhibition of cholesterol synthesis and anti-bacterial activity [35, 36].

The Alkaloid and Calorific determination of EPGL reveals the biological value of Punica granatum Leaves (table 3). Carbohydrate content was found high (19.6\% of dry matter) followed by protein ( $11.86 \%$ of dry matter) and alkaloid content (3.5\% of dry matter) whereas lipid content was found very low i.e., $0.96 \%$ of dry matter. The presence of higher protein level in the plant parts shows their possible increased food value or that a protein based bioactive compound could also be isolated in future. Punica granatum leaves have a low level of lipid is an indication that it would have little cholesterol. Alkaloids which are one of the largest groups of phytochemicals in plants have amazing effects on humans and this has led to the development of powerful pain killer medications [37]. Also, studies have shown that alkaloid is capable of reducing headaches associated with hypertension [38].

\section{CONCLUSION}

Nowadays herbs are extensively used for the research purpose and it possesses more than one chemical entity so it has been widely used for the research investigations. The plant based compounds have the effective dosage response and minimal side effects when compared to the synthetic compounds Phytochemical screening of Punica granatum leaves reveals it as a valuable medicinal plant with numerous medicinal properties. Since the ethanolic extract of $P$. granatum leaves contains more constituents it can be considered beneficial for further investigation. A typical research and developmental work needs to be carried out for its better therapeutic and commercial utilization.

\section{CONFLICT OF INTERESTS}

Declare none

\section{REFERENCES}

1. Ngari EW, Chiuri LW, Kariuki ST, Huckett S. Ethnomedicine of ogiek of river njoro watershed. Ethnobot Res Appl 2010;8:135-52.

2. Lingarao $M$, Savithramma N. Phytochemical studies of svensonia hyderobadensis (Walp.) Mold-arare medicinal plant: Der Pharm Lett 2011;3:51-5.

3. Sodipo OA, MA Akanji, FB Kolawole, Odutuga AA. Saponin is the active antifungal principle in Garcinia kola, heckle seed. Biosci Res Commun 1991;3:171-1.

4. Mc Mahon JB, Currens MJ, Gulakowski RJ, Buckheit RWJ, Lackman-Smith C, Hallock YF, et al. Michellamine B a novel plant alkaloid, inhibits human immunodeficiency virus-induced all killing by at least two distinct mechanisms. Antimicrobial Agents Chemother 1995;39:484-8.

5. Noble RI. The discovery of Vinca alkaloids chemotherapeutic agents against cancer: Biochem. Cell Biol 1990;68:1544-51.

6. Prasanth Tiwari, Bimlesh Kumar, Mandeep Kaur, Gurpreet Kaur, Harleen Kaur. Phytochemical screening and extraction: review. Int Pharm Sci 2011;1:98-106.

7. Das K, Tiwari RKS, Shrivastava DK. Techniques for evaluation of medicinal plant products as antimicrobial agent: current methods and future trends. J Med Plant Res 2010;4:104-11.

8. Egharevba HO, Kunle OF. Preliminary phytochemical and proximate analysis of the leaves of Piliostigma thionningii (Schumach.): milne-redhead. Ethnobot Leaflets 2010;14:570-7.

9. Naqvi SA, Khan MS, Vohora SB. Antibacterial, antifungal, and antihelminthic investigations on Indian medicinal plants: Fitoterapia 1991;62:221-8.
10. Jayaprakasha GK, Negi PS, Jena BS. Antimicrobial activities of pomegranates, in pomegranates; ancient roots to modern medicines, Eds., CRC Press: Boca Raton, FL, USA; 2006. p. 167-8.

11. Singh RP, Chidambara MKN, Jayaprakasha GK. Studies on the antioxidant activity of pomegranate (Punica granatum) peel and seed extracts using in vitro models: J Agric Food Chem 2002;50:81-6.

12. Sofowara A. Screening plants for bioactive agents. In: Medicinal plants and traditional medicinal in Africa. $2^{\text {nd }}$ edition. Spectrum Book Ltd, Sunshine House, Ibadan Nigeria; 1993. p. 134-56.

13. Trease GE, Evans WC. Pharmacognosy. 15th ed. Sounders Publishers. London; 2002. p. 42-44, 22-229, 246-249, 304-306, 331-332, 391-393.

14. Singleton VL, Rossi JA. Colorimetry of total phenolic with phosphomolybdic acid-phosphotungstic acid reagents. Am J Enol Viticulture 1965;16:144-58.

15. Vishnoi NR. Advanced practical chemistry ghaziabad-India; Yikas Publication House, Pvt Ltd; 1979. p. 447-9.

16. El-falleh W, Hannachi H, Tlili N, Yahia Y, Nasri N, Ferchichi A. Total phenolic contents and antioxidant activities of pomegranate peel, seed, leaf and flower. J Med Plants Res 2012;6:4724-30.

17. Peri C, C Pompei CJ. Estimation of different phenolic groups in vegetable extracts. Phytochemistry 1971;19:2187-9.

18. Samantha T, Shyamsundarachary R, Srinivas, P, Swamy NS. Quantification of total phenolic and total flavonoid contents in extracts of oroxylum indicum L. Kurtz. Asian J Pharm Clin Res 2012;5:177-9.

19. Patel AN, Bandawane DD, Mhetre NK. Pomegranate (Punica granatum Linn.) leaves attenuate disturbed homeostasis and hyperglycemia mediated hyperlipidemia and oxidative stress in streptozotocin induced diabetic rats. Eur J Integrative Med 2014;6:307-21.

20. Lu ZM, Gong Js, He Z, Xu HY, Dou WF, Shi JS, et al. Optimization of extraction of total triterpenoids from submergedly cultivated Antrodia Camphorata using response surface methodology. Nat Prod Res Dev 2011;23:946-51.

21. Hedge JE, Hofreiter BT. In: Methods in carbohydrates chemistry. Vol. Eds. Whistler RL, BeMiller JN. Academic Press: New York; 1962. p. 17:.420.

22. Lowry $\mathrm{OH}$, Roseobrough NJ, Farr AL, Randall RJ. Protein measurement with folin phenols reagent. J Biol Chem 1957;93:265-75.

23. Cheung PCK, Leung AYH, Ang PO. Comparison of supercritical carbon dioxide and Soxhlet extraction of lipids from a brown seaweed, Sargassum hemiphyllum (Turn.) C: Ag J Agric Food Chem 1998;46:4228-4232.

24. Harborne JB. Phytochemical methods, London. Chapman and Hall, Ltd; 1973. p. 49-188.

25. Clark TE, Appleton CC, Drewes SE. A semi-quantitative approach to the selection of appropriate candidate plant molluscicides-a South African application. J Ethnopharmacol 1997;56:1-13.

26. Marston A, Maillard M, Hostettmann K. Search for antifungal, molluscicidal and larvicidal compounds from African medicinal plants. J Ethnopharmacol 1993;38:215-23.

27. Adewunmi CO, Adesina SK, Marquis VO. On the laboratory and field evaluation of the molluscicidal properties of tetrapleura tetraptera. Bull Anim Hlth Prod Afr 1982;30:89-94.

28. Pande G, Akoh CC. Antioxidant capacity and lipid characterization of six georgia-grown pomegranate cultivators. J Agric Food chem 2009;57:9427-36.

29. Hemayat Hossain, Tanzir Ahmed, Sariful Islam Howlader, Shubhra kanti Dey, Arpana Hira, Arif ahmed, et al. In vitro antioxidant potential from the leaves of punica granatum Linn. Grown in Bangladesh. Int J Pharm Phytopharmacol Res 2012;2:160-6.

30. Mir MA, Sawhney SS, Jassal MMS. Qualitative and quantitative analysis of phytochemicals of taraxacum officinale. Wudpecker J Pharm Pharmocol 2013;2:1-57.

31. Stevens JF, Hart HT, Hendriks H, Malingre TM. Alkaloids of some European and macaronesian diode and semepervivodeae (Crassulaceae). Phytochemistry 1992;31:3917-24.

32. Asha K, Rasika CT, Nirmala RD, Jyoti PS. Antioxidant potential from Stem Bark of Juglans regia L. Ann Biol Res 2011;2:176-80. 
33. Igboko DO. Phytochemical studies on Garcinia Kola Heckel. M.Sc. Thesis. University of Nigeria, Nsukka; 1983. p. 202.

34. Maiduyi I. Biochemical and pharmacological studies of active principles of the seeds of Garcinia kola Heckel; MSc. Thesis, University of Nigeria, Nsukka; 1983. p. 108.

35. Guangyi Wang, Weiping Tang, Robert R, Bidigare. Terpenoids as therapeutic drugs and pharmaceutical agents: Natural Products; 2005. p. 197-227.

36. McGarvey DJ, Croteau R. Terpenoid metabolism. Plant Cell 1995; 7:1015-26.
37. Kam PC, Liew A. Traditional Chinese herbal medicine and anaesthesia. Anaesthesia 2002;57:1083-9.

38. Ayitey-Smith E, Addae-Mensah I. Phytochemical, nutritional and medical properties of some leafy vegetables consumed by Edo people of Nigeria. W Afr J Pharmacol Drug Res 1977;4:7-8.

\section{How to cite this article}

- P Sreedevi, K Vijayalakshmi, R Venkateswari. Phytochemical evaluation of Punica granatum L. leaf extract. Int J Curr Pharm Res 2017;9(4):14-18. 